\title{
Improving Students' Ability in Writing Recount Text Using Peer Correction
}

\author{
Reski Novitasari, Martono, Teguh Sarosa \\ English Education Department \\ Teacher Training and Education Faculty \\ Sebelas Maret University of Surakarta
}

Email: reski_novita55@yahoo.co.id

\begin{abstract}
This article discusses the implementation of Peer Correction technique to improve the students' ability in writing a recount text at a senior high school in Wonogiri. This research aimed to know how Peer Correction technique can be implemented effectively to improve the students' writing ability and to what extent the improvement can be achieved. The qualitative data were collected through observation, questionnaire, and interview. While quantitative data were obtained from the students' tests. The findings submitted that: 1)Peer Correction can be implemented effectively because of the students' learning awareness during the correction process which help them to get a better reflection related with their own future written tasks and it must be supported with an adequate feedbackespecially face-to face feedback, 2) it could improve the students' writing competence viewed from the improvement in the five aspect namely grammar, content, vocabulary, mechanic, and organization, 3) it also makes a better classroom dynamic during the writing class. As the finding of this research has not yet investigated the effect on self-evaluation, further researches might be in a longer period are highly recommended.
\end{abstract}

Keywords: peer correction, writing skill, recount text.

\section{INTRODUCTION}

Ferris and Hedgcock (2005, p,208) stated that there are many studies have been discussed about the effectiveness of written and oral feedback or response in teaching writing. Teacher response to students' writings is important at all levels and in all instructional contexts. However, responding effectively to student writing is a skill that can elude even for the experienced teachers. In addition, they also stated that written teacher feedback has most typically been regarded by L1 and L2 researchers as a necessary evil, burdensome to writing teachers and limited in its effectiveness to help the students to improve their literacy skills in writing. Besides, the effectiveness of oral feedback also has been discussed recently. As what Ferris and Hedgcock (2005, p.203) stated that there is another important means of giving feedback and instruction to writing students which is through oral feedback namely one-to-one writing conferences. In decades, the writing conference has achieved widespread popularity as a teaching means for several reasons. One consideration is that writing conferences save teachers time and energy that would otherwise be spent in marking students' papers. Another concern is the immediacy and potential for interaction and negotiation that the conferencing event 
offers, allowing for on-the-spot clarification of difficult issues or problems.

This article deals with the use of Peer Correction mehod which provides both written and oral feedback in improving students' writing competence. Before the technique was implemented, the writer conducted pre research which contains of several activities like observation, questionnaire, interviews, and pre test.Based on the pre-research data, the writer found that there were several problems in the students' writing competences. Regarding with the pre test done by the students, the students' scores were far above the Standart Minimum Score. The students' low scores was caused by the students' writing competence which was still low. It happened because the teacher did not provide an adequate feedback in the students' writings. By looking at the students' problems in this study, the writer analyses that the students need both written and oral feedback. Peer correction method is a technique which conveys those two kinds of feedback. The written feedback is obtained from the peer response which is also monitored by the teacher. Then, oral feedback is obtained from the teacher feedback during the correction process and after the editing process.

According to Richards, et.al (1992), peer correction is an activity in the revising stage of writing in which students receive correction about their writing from other students-their peers. Typically students work in pairs or small groups, read each other's compositions and ask questions or give comments or suggestions. Peer writers can edit their own written compositions basing on the readers' remarks and comments (Rollison, 2005), so the writers can be better at learning writing. Hansen and Liu (2005) said that peer correction is supported by a number of theories: process-oriented writing, cooperative learning, and interaction and scaffolding in language learning. Pedagogically, peer correction assumes that students play the role of trained peer reviewers whose task is to give a commentary on their partners' drafts in either written or spoken mode during composition lessons., in teaching using peer correction, the teacher's role are three-folds: (1) dividing the students into groups, (2) providing them with guiding points or questions, and (3) checking the final version of the composition. The students' task is to respond (i.e. correct, edit, review, assess, etc.) to each other's drafts inline with the teacher's guiding points and produce the final version following their peers' response.

In peer correction process, there are two kinds of feedback namely teacher feedback and peer feedback. Ferris and Hedgcock (2005,p: 226) determined that both L1 and L2 teachers and researchers have claimed that peer feedback activities in the classroom offer many advantages. For novice writers in general, whether native speakers (NSs) or non-native speakers (NNSs), the following benefits have been suggested:

a) Students can take active roles in theirown learning (Hirvela, 1999; Mendonça \& Johnson, 1994),

b) Students receive "reactions, questions, and responses from authentic readers" (Mittan, 1989, p, 209);

c) Student receive feedback from multiple sources (Chaudrbn, 1983; Mittan, 1989),

d) Responding to peers' writing builds the critical skills needed to analyse and revise one's own writing (Leki, 1990; Mittan, 1989).

e) Peer response activities build classroom community (Ferris, 2003) 
Harmer (2005) established that this peer correction is a valuable element in the writing process; it encourages students to work collaboratively and reduces student's reluctance in the editing process. Besides, the students will be able to develop the skill of revising and checking their own process of learning. Even though this is an effective process, it still needs the teacher's feedback for knowing the focus and the way they checked a classmates' written product. Regarding the advantages, Bartels (2003) agreed with Hyland (2000) and Topping et al. (2000) that peer correction gives the students the feeling that they write for an audience and that it motivates them and increases their confidence in their writings. From that motivation, it will lead the students to do their best and be maximal for their writing products.

By considering the advantages of peer correction method, the writer proposed Peer Correction to improve her students' ability in writing and conducted a research. The research was conducted to find out 1) how Peer Correction method was implemented effectively to improve students' ability in writing recount text?, 2) to what extent Peer Correction improved the students' ability in writing recount text

\section{RESEARCH METHODS}

In this study, the writer used classroom action method. Action research has a great deal with education. This kind of research has apparently been broadly conducted by educators as an effort of improving or refining education. According to Elliott (1991: 69), action-research might be defined as 'the study of a social situation with a view to improving the quality of action within it'. It aims to feed practical judgement in concrete situations, and the validity of the 'theories 'or hypotheses. Thus, Classroom Action Research is equivalently defined as a process of inquiry - say, for instance, investigating, reflecting, and evaluating - to perceive educational problems for an improvement which is conducted in a classroom. Simply said, a Classroom Action Research enables the practitioners to make improvement in teaching learning process.

The model of action research in this study is adopted from Arikunto (2007: 9) which refers to Kemmis development of Lewis' cycle that includes four phases which are: 1)Planning (analysing pre research result; making lesson plan and the action procedures; preparing students list and scoring rubric; preparing tools for teaching and learning observation like digital camera; and preparing post test), 2) Acting ( the stages of peer correction method areimplemented),

3) Observing (observation notes are taken),

4) Reflecting (data obtained are analysed, the process of finding the strength and weakness). In this study, the writer used the kind of Action Research which is participatory/participant type of research because the researcher becomes both the observer and the teacher.

In the collecting data process, the writer used three methods which are taken from Sagor (2000). They are existing data which involves both students' recordings and students' works, observation data which are taken in pre-research; during the implementation and post implementation, and probe data which involves the students' test and interviews. While in analysing the data, the writer uses two methods which are quantitative and qualitative technique. In quantitative data, the writer uses the technique in analysing the mean scores or the total percentage of the students' scores. Then, in qualitative data, the writer uses three steps in getting the descriptive statistic. They are namely 1) data reduction that refers to the process of selecting, focusing, simplifying, 
abstracting and transforming the 'raw 'data that appear in written up field notes, 2) data display which helps the researcher to understand what is happening and to do something - further analysis or action -based on that understanding, and 3) conclusion drawing/verification. This research was conducted at the tenth grade of SMA N 2 Wonogiri in the academic year 2014/2015. The total students are thirty three students. This research was conducted from March until May 2015 in two cycles.

\section{RESEARCH FINDINGS AND DISCUSSIONS}

This research had gone through preresearch activity and two cycles for the implementation of peer correction technique. Table 1 describes the writing competence related with five aspects in writing skill. Table 2 depicts the classroom situation during writing class.

After the activities on Cycle 1 and Cycle 2 had been conducted, there were some results obtained in writing class. They were improvement on students' writing competence related with five aspects in writing skill and 2) the improvement on their class condition or classroom dynamic. The description about the detail process in obtaining those findings in each cycle are described in the next following paragraph.

\section{The students' ability in writing a recount text improved.}

From post tests result, it was inferred that the students' ability related with five writing indicators had improved by using Peer Correction technique. The most significant difference was in the aspect of grammar. It was caused from the process in correcting process. During the correcting process, the students discuss collaboratively in their groups and pairs. They share opinions in finding the other grammar errors. Besides, during the correction process, face to face feedback from the teacher is really useful to help students overcome their confusions or difficulty. It was in line with McCarthey (1992: p,1) who determined that feedback on student writing through face-to-face conferencing has important advantages as it can supplement the limitations of one-way written feedback with opportunities for "the teacher and the student to negotiate the meaning of a text through dialogue". In addition, Hyland(2003: p,192) supported that the interactive nature of the conference gives teachers a chance to respond to the diverse cultural, educational, and writing needs of their students, clarifying meaning and resolving ambiguities, while saving them the time spent in detailed marking of papers. In line with his previous theory, Hyland (2000) also determined that in writing, interactive conferences not only assist learners with auditory learning styles, but give them a clearer idea of their strengths and weaknesses, develop their autonomy skills, allow them to raise questions on their written feedback, and help them construct a revision plan.

The students' writing competence improved better because the students were provided with meaningful activities conveyed by peer correction method. Meaningful activities conveyed in Peer Correction such as correcting another draft, sharing in giving comment toward the peer's draft, discussing in finding the errors and discussing in knowing the right or proper ones. This technique was began by drafting text collaboratively in group or in pairs. The second activity was correcting or editing process by another group or pair. During the correction process, the students are allowed to ask questions. So, the teacher's feedback is really needed here. 
Table 1. Findings on the writing competence during the research

\begin{tabular}{|c|c|c|}
\hline Before research & Cycle 1 & Cycle 2 \\
\hline $\begin{array}{l}\text { - They could not } \\
\text { differentiate present } \\
\text { and past tense. They } \\
\text { could not use the past } \\
\text { tense in a writing } \\
\text { activity correctly. } \\
\text { Almost all of the } \\
\text { students felt difficult in } \\
\text { developing their main } \\
\text { idea into several } \\
\text { sentences. They did not } \\
\text { elaborate their ideas } \\
\text { well. } \\
\text { Many of the students } \\
\text { had a limited range of } \\
\text { vocabulary and } \\
\text { sometimes had errors } \\
\text { spellings. Even some of } \\
\text { the students had similar } \\
\text { words choice. } \\
\text { Several students still } \\
\text { ignored the use of } \\
\text { several punctuation } \\
\text { such as period, and } \\
\text { comas } \\
\text { Some of the students } \\
\text { still had problems in } \\
\text { organizing the recount } \\
\text { text correctly. } \\
\text { (organization aspect) } \\
\text { Several students still } \\
\text { ignored to give title or } \\
\text { re- orientation part in } \\
\text { their recount text. }\end{array}$ & $\begin{array}{l}\text { - The students began to curious about } \\
\text { the difference between present and } \\
\text { past tense. They started to ask } \\
\text { questions, asked for teacher's } \\
\text { confirmation. } \\
\text { Through the feedback from teacher to } \\
\text { whole class, almost all the students } \\
\text { had understood about the use of past } \\
\text { tense. As a result, in post test } 1 \text {, almost } \\
\text { all students could write their own } \\
\text { recount text using past tense } \\
\text { appropriately } \\
\text { The students were couraged by the } \\
\text { teacher to develop their ideas and to } \\
\text { elaborate it more. Half of the students } \\
\text { successfully achieved the limit of } 80 \\
\text { words in their text. } \\
\text { Almost all the students could } \\
\text { overcome their spelling errors. They } \\
\text { wrote their post test } 1 \text { in a good } \\
\text { spelling. } \\
\text { The teacher gave lecturing about the } \\
\text { use of punctuation (period, commas, } \\
\text { and capitalization). It helps the } \\
\text { students to be aware of its use. But } \\
\text { still there some of the students who } \\
\text { make a mistake (slips mistakes). } \\
\text { Through the feedback from teacher, } \\
\text { many of the students had understood } \\
\text { the importance, the definition of title } \\
\text { and re- orientation. } \\
\text { Only several students who still forgot } \\
\text { to give title and re- orientation part in } \\
\text { their recount text. }\end{array}$ & $\begin{array}{l}\text { - Using teacher feedback, all the } \\
\text { students were not confuse } \\
\text { anymore about the use of active } \\
\text { and passive sentence form. They } \\
\text { could write a recount text in a } \\
\text { appropriate tense and in a good } \\
\text { sentence form. } \\
\text { - All of the students were able to } \\
\text { develop their ideas into a whole } \\
\text { recount text. } \\
\text { - Almost all of the students had } \\
\text { good word spelling and had } \\
\text { good vocabulary mastery. } \\
\text { Almost all the students had good } \\
\text { mechanic. They used period and } \\
\text { coma properly. They also pay } \\
\text { attention to the capitalization } \\
\text { rules. } \\
\text { All the students could make title, } \\
\text { re- orientation part easily and } \\
\text { they always inserted those parts } \\
\text { in their recount text. }\end{array}$ \\
\hline
\end{tabular}

After correction process finished, they should give the draft back to the writer. The next activity was giving feedback. The feedback can come from the teacher or the students itself. In this research the feedback was often given by the researcher as the teacher. As a result, the feedback and the correction got by the students were used by them in drafting their own text.

Secondly, the students' mean score in content and organization aspect also enhanced significantly. It is caused by the students' self confidence in writing which improved better. They are motivated to write a more fully text because they feel that they have audience that will read their texts. Besides, the teacher also encourages the students to give more elaboration in their text. The teacher also always reminds the students about the organization of recount text. 
Table 2. Findings on the classroom situation during the research

\begin{tabular}{|c|c|c|}
\hline Before research & Cycle 1 & Cycle 2 \\
\hline $\begin{array}{l}\text { - The students were passive } \\
\text { during writing class. Only } \\
\text { several students who paid } \\
\text { attention to the teacher. The rest } \\
\text { of the students were busy with } \\
\text { their selves and had chat with } \\
\text { other classmates. } \\
\text { - The dynamic classroom } \\
\text { situation went in one-way } \\
\text { communication. The one-way } \\
\text { communication was only } \\
\text { between teacher to students and } \\
\text { vice versa. Because the teacher } \\
\text { often used lecturing method in } \\
\text { her writing class. } \\
\text { - Monotonous writing activities. } \\
\text { It was always begun with } \\
\text { lecturing. Secondly, giving tasks } \\
\text { to the students. Then, submitting } \\
\text { tasks to the teacher. Finally, } \\
\text { when the teacher had scored the } \\
\text { tasks, she gave the tasks back to } \\
\text { the students without an adequate } \\
\text { feedback }\end{array}$ & $\begin{array}{l}\text { - The students were not familiar } \\
\text { yet with peer correction as } \\
\text { writing teaching method. They } \\
\text { confused how the learning } \\
\text { process will be but they enjoyed } \\
\text { the lesson. Because they know } \\
\text { that they will work in group and } \\
\text { pairs. So, they focused on the } \\
\text { lesson and enjoyed the teaching } \\
\text { activities. All the studentscould } \\
\text { work cooperatively and } \\
\text { finished their works punctually. } \\
\text { The dynamic classroom began } \\
\text { to change from one-way into } \\
\text { two- way communication. } \\
\text { There was communication } \\
\text { between teacher to groups and } \\
\text { vice versa. } \\
\text { Almost all of the students } \\
\text { enjoyed their new learning } \\
\text { process (drafting in group, } \\
\text { correcting in group, discussing } \\
\text { in group) }\end{array}$ & $\begin{array}{l}\text { - All of the students participated } \\
\text { actively in all activities during } \\
\text { Peer Correction method was } \\
\text { being implemented. } \\
\text { The communication ways } \\
\text { extended into teacher to pairs, } \\
\text { teacher to student, pairs to } \\
\text { pairs, student to student and } \\
\text { vice versa. The classroom } \\
\text { dynamic improved better. This } \\
\text { made the classroom situation } \\
\text { became interesting and joyful } \\
\text { for the students. } \\
\text { The learning process was no } \\
\text { longer monotonous. The } \\
\text { writing class was not only } \\
\text { dominated by lecturing } \\
\text { method. There were several } \\
\text { meaningful activities provided } \\
\text { by Peer Correction such as, } \\
\text { lecturing, drafting in } \\
\text { groups/pairs, correcting in } \\
\text { groups/pairs, revising their } \\
\text { draft together, discussing ideas } \\
\text { together) }\end{array}$ \\
\hline
\end{tabular}

The improvement in the vocabulary aspect emerged because of the students' vocabulary mastery which improved during the editing process. Before this study was implemented, the students' problem was not only about vocabulary mastery but also about spelling. Many of the students wrote in incorrect spelling of words. After each writer got corrected by another peer, their awareness in spelling increased better. They were told the correct spelling; they were reminded to be more careful in writing an involute or difficult word. As a result, they become more careful in spelling words. In enhancing the students' vocabulary mastery, the teacher uses the editing process to help them in improving their vocabulary mastery. Before the students correct another peer's draft, they have to read carefully to the whole text. Generally, they will find new vocabularies from another peer's text. When they do not understand the meaning of those new words, consequently they will look for the meanings in a dictionary. As a result, they enrich their vocabulary mastery and use their better knowledge in writing their own future texts. As the other aspect, the students' mean score in the mechanic aspect also enhanced significantly. In the pre test, almost all students ignored the use of period and commas. In arousing the students' awareness about mechanic, the teacher gives a lecturing about the use of capitalization, the use of period, commas, semicolon, and etc. It makes the students so aware in correcting the mechanic aspect of their friends' text. Besides, when the students write their own recount text, they are no longer avoiding the use of mechanic. They use period, commas, and capitalization appropriately.

The students' improvement in the writing competence not only can be seen 
from the process of learning but also from their score in post test 1 and post test 2 . These following table and graph describe the students' improvement related with their writing competence seen from the quantitative data.

\section{The classroom dynamic improved better.}

Another finding in this study is related with the classroom situation in teaching learning process. Through the observation data, the class condition was better than the previous writing class. It could be seen from the students' participation which increased. It was caused by the students' motivation which aroused. Because the students felt that this Peer Correction technique was new and interesting for them. Besides listening to the teacher's feedback, the students also got meaningful activities through drafting recount text together, correcting process, and discussing process. In other words, peer correction provides the students in a collaborative learning process. As stated by Carson \& Nelson: 1994, pp. 1718 that peer response is the notion of collaborative learning which derives from the social constructionist view that knowledge is essentially a socially justified belief.

During cycle I and cycle II, the students were more motivated in correcting their peer's draft. They were not shy to ask questions and delivered their opinions. While, using interview data, the students felt that this Peer Correction technique successfully improved not only their writing ability but also the classroom dynamic. It can be seen form the fact that peer correction improved the communication way in the learning process. Before the research was implemented, the communication only flew from teacher to the whole class. By applying peer correction technique, the communication way changes into two - way communication. The communication run well between students to the teacher, students- to students, teacher to group and teacher to the whole class. It can be concluded that peer correction successfully arouses the students motivation in learning and help them to have a better communication skill. It is in line with Mangelsdorf (1989) highlighted specific benefits of peer response for L2 students' linguistic development, nothing that peer interactions build communication skills and provide important opportunities for students to test and revise their L2 hypotheses.

Meanwhile, the students' questionnaire also showed that there were 97 $\%$ of the students who agreed that Peer Correction could make the classroom situation became more alive, interesting and not boring. These situations were caused by the several of meaningful activities in the Peer Correction technique. The various activities were drafting process, correcting process, discussing, sharing, communicating, and listening to teacher's feedback. This good classroom situation at the end made the students became maximal in doing their writing activity. Finally, as a result their writing competence could improve and pass the Standard Minimum Competence. 
Table 3. Students' mean score comparison based on each indicator (Pre test and Post test 1, and Post test 2)

\begin{tabular}{llllll}
\hline No. & $\begin{array}{c}\text { Indicators of } \\
\text { Writing }\end{array}$ & $\begin{array}{c}\text { Max } \\
\text { score }\end{array}$ & Pre test mean score & $\begin{array}{c}\text { Post test 1 mean } \\
\text { score }\end{array}$ & $\begin{array}{c}\text { Post test 2 } \\
\text { mean score }\end{array}$ \\
\hline 1 & Content & 30 & 21.06 & 23.31 & 23.55 \\
2 & Organization & 20 & 16.04 & 16.36 & 16.44 \\
3 & Vocabulary & 20 & 14.13 & 16.02 & 16.20 \\
4 & Grammar & 25 & 15.68 & 18.10 & 20.92 \\
5 & Mechanic & 5 & 4.15 & 4.40 & 4.70 \\
6. & WRITING & $\mathbf{1 0 0}$ & $\mathbf{6 8 . 9 8}$ & $\mathbf{7 7 . 0 4}$ & $\mathbf{8 1 . 8 2}$ \\
& SCORE & & & & \\
\hline
\end{tabular}

Graph 4. The improvements of students' mean score from pre test, post test 1 , and post test 2 .

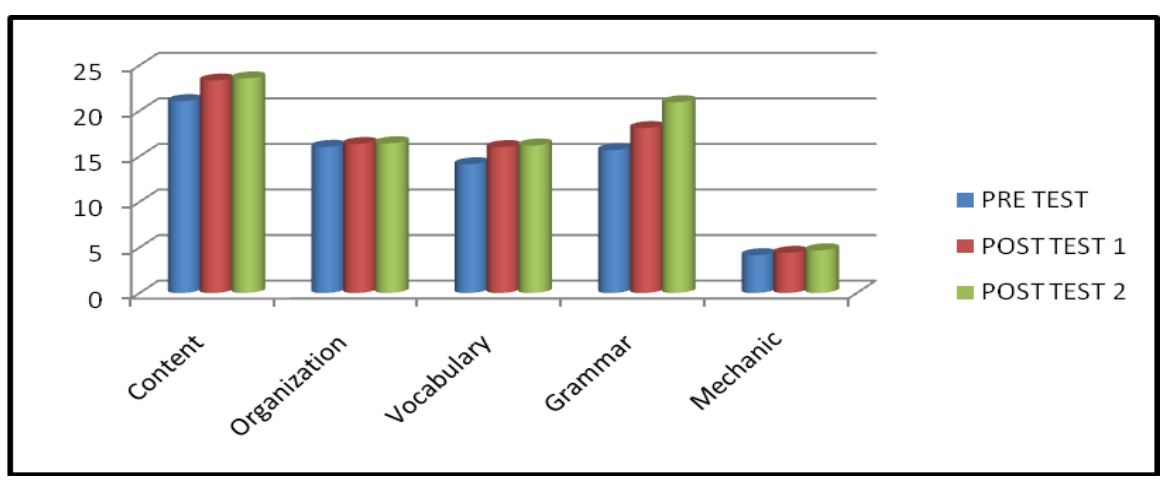

Chart 5. The improvement of the students' writing score.

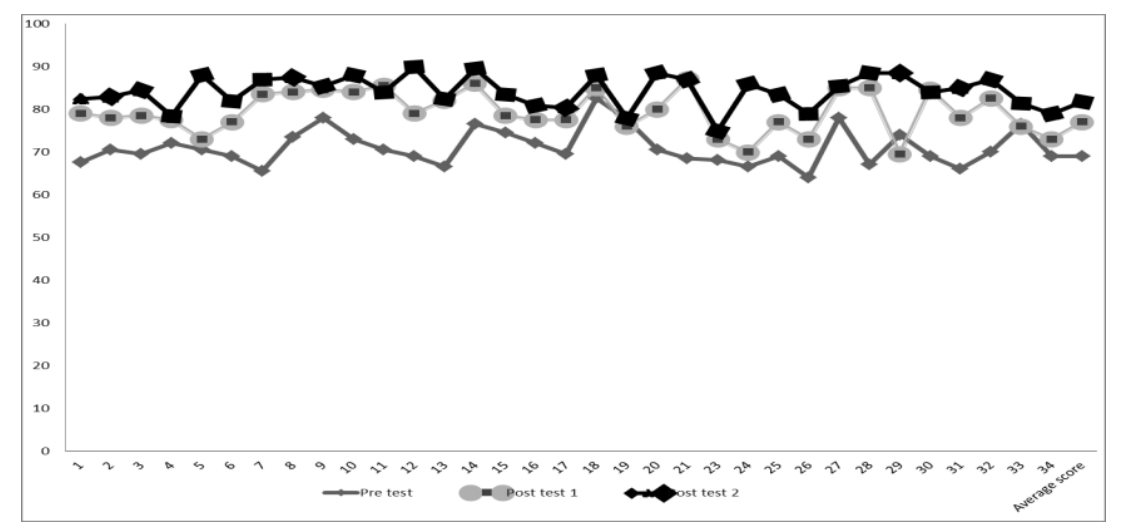




\section{CONCLUSIONS AND SUGGESTIONS}

As this research departs from two main research questions, those are (1) how can peer correction technique be implemented effectively? and (2) to what extent can it improve the students ability in writing a recount text? The conclusion is respectively elaborated based on those two concerns.

First, peer correction technique can be implemented effectively to improve the students' writing competence by maximizing the use of written and oral feedback during this technique was implemented. The teacher should maximize the written feedback from the peer response through peer correction chart. When it does not give enough contribution toward the students' problem, the oral feedback from the teacher should be taken place.

Secondly, the students' writing competence improved by applying Peer Correction technique. It can be seen from the improvement of students' score from pre test to post test. The students' writing ability improvement is seen from the improved writing indicator score. The writing indicators which were scored in this research were content, organization, vocabulary, grammar, and mechanic.

In addition, Peer Correction shows its impact toward the classroom situation. The situation of teaching and learning process was improved better by this technique. In detail, after the implementation of Peer Correction, the students acknowledge that they become more active in writing class. They feel like they are given a big role in making the learning process successful. They get new role besides become a writer and listener like in their previous writing class. In Peer Correction technique, they get a new role as a corrector. As a result, they have a better ability in correcting, revising, and communicating. Their critical thinking is also improved. The classroom situation becomes noisier because there are many students who ask questions, many students who discuss with their group or with their partner. This activity made the writing class become not boring. This also makes the communication in classroom dynamic run well. The communication is not only between teacher to students but also teacher to group, group to group, student to student, and teacher to the whole class.

\section{BIBLIOGRAPHY}

Bartels, N. (2003). Written peer response in L2 writing. English Teaching Forum,4: 34-38.

Carson, J. \& Nelson, G. L. (1994). Writing groups: Cross-cultural issues. Journal of Second Language Writing, 3,17-30.

Elliott, J. (1991). Action Research for Educational Change. Milton Keynes: Open University Press

Ferris, D.R \& Hedgcock, J.S (2005). Teaching ESL Composition. Purpose, Process, and Practice. New Jersey: Lawrence Erlbaum Associates Publisher London

Hansen, J. and Liu, J (2005). Guiding principles for effective peer response. ELT Journal, 59: 31-38.

Harmer, J. (2005). The Practice of English Language Teaching. London:

Pearson-Longman

Hyland, K. (2003). Second Language Writing. Cambridge: Cambridge University Press.

Kemmis, S. (1988). Action Research: Educational Research, Methodology, 
and Measurement. Oxford:Pergamon Press.

McCarthey, S. J. (1992). The teacher, the author, and the text: variations in form and content of writing conferences. Journal of Reading Behaviour, 24(1), 51-82.

Mangelsdorf, K. (1989). Parellels between speaking and writing in second language acquisition. In D. M. Johnson \& D. H. Roen (Eds.), Richness in writing: Empowering ESL students (pp. 134-145). New York: Longman.

Richards, J. C and Renandya, W. A (2002). Methodology in Language Teaching.
Cambridge, England: Cambridge University Press

Rollinson, P. (2005). Using peer feedback in the ESL writing class. ELT Journal, 59: 23-30.

Sagor, Richard. (2005). The Action Research Guidebook: A Four-Step Process for Educators and School Teams. California: Corwin Press.

Topping, K.J., Smith, E.F., Swanson,I., and Elliot, A. (2000). Formative Peer Assessment of Academic Writing Between Postgraduate Students, Assement \& Evaluation in Higher Education. 25(2). pp. 149-169 